\title{
8
}

\section{EDUCATION AND EARNING IN EDO AND DELTA STATES OF NIGERIA ${ }^{1}$}

\author{
Ben E. Aigbokhan
}

\begin{abstract}
Education is widely recognised as a major source of economic growth through its effect on productivity. Most developing countries made giant strides in the decades up to the 1970s in terms of creating access to education by committing sizeable funds to the sector. However, since the 1980s, in the face of pressing economic problem, many countries cut back on their investment in education. In the face of declining educational quality and access, there have been calls for increased allocation of financial resources to the sector.

This paper examines, as a basis of assessing the justification of allocating more funds to education more specifically but critically, the rationale of the call for return to education.

This is done at four levels of classification, namely, by level of educational attainment, by sex, by employment category, and by geographical sector.

The results show that return to education is positive and rises with more education, thus justifying the call for more resources. The results also show that there is mixed evidence on return to education by sex in the two states. There are similarly mixed evidence with regard to sector and employment category. However, the fact that some differentiation in return to education by these levels of categorisation exists is suggestive of the existence of dual labour market, albeit a rough indication. There is thus the need for public policies to further integrate the labour market, at least because of the implication for rural-urban migration and for equity.
\end{abstract}


92 Annals of the Social Science Council of Nigeria, No.4, 1992.

\section{INTRODUCTION}

Education has for a long time been recognised as a major source of economic growth and development. The success of policies to promote growth and sustained development hinges largely on the existence of well-educated labour force and population. In recognition of this, developed countries have continually launched educational reforms to prepare students better for the labour market. Developing countries, however, faced with economic crisis and high population growth as well as limited resources have been hard pressed to maintain the already low educational quality and access.

There have been calls for increased public spending on education. Some have argued for increased private funding in the face of dwindling public funding, either through students' loans, increased parental contributions or corporate sector contribution. All these suggest the need to treat educational financing' as a form of investment. Decisions to commit funds would, therefore, need to be influenced by the expected returns to education.

Also, in the past few years the observation has been made in the literature that there is a gender gap in access to education, to the effect that females have less access to educational opportunities.' This tends to suggest that there is gender differential return to education, otherwise there would not have been any economic justification for such discrimination argument.

Another aspect of the dual labour market issue is sectorial differential in earnings. Although the issue has been investigated by some in the context of public versus private sector pay differential, (Psacharapoulous, 1983), it is important to examine the theory in the context of urban-rural migration. And on a broader level, the issue of dualism has implications for equality, as analysis of sectorial and gender differentials in earnings would indicate differential contributions to equity.

The purpose of this paper, therefore, is to demonstrate empirically the return to education by educational level, by sex, by geographical sector of employment, and by employment category in Nigeria, using individual data from a survey of Edo and Delta states. The second section presents a brief discussion of some issues on education and the economy, as well as trends in educational spending and enrolment in Nigeria. The third section presents the earnings model and discussion of the estimated results, while the final section concludes the discussion.

\section{ISSUES AND TRENDS IN EDUCATION IN NIGERIA}

Education is widely recognised as a channel for raising living standard. Through acquisition of basic and vocational training, workers are able to improve their productivity and be better able to learn new skills. Where earnings are related to productivity, the more educated would, other things being equal, be able to earn higher incomes and thereby be able to enjoy higher living standard.

Moreover, it has been observed that education of females stems population growth as well as spreads better health and nutrition. Because these effects accumulate from one generation to the next, it has been argued 


\section{Education and Earning in Edo and Delia States 93}

that female education should be widespread, otherwise it may result in inequality in the society (Vespoor, 1990).

Since free primary education was introduced in Nigeria in the mid-1950s, there have been heavy investments in education by governments. Student enrolment rose rapidly until the 1970s. Primary enrolment, as a percentage of school-age children, rose from $42 \%$ in 1973 to $98 \%$ in 1980 . However, in the 1980 s, there was a decline to $77 \%$ and $70 \%$ in 1985 and 1989 respectively. Secondary enrolment, as a percentage of school-age children, rose from 9\% in 1973 to $21 \%$ in 1980 and to $29 \%$ in 1985 from which it fell to $19 \%$ in 1989 . University enrolment displayed a similar trend. Female enrolment has generally been on the increase, with primary enrolment as a percentage of total primary enrolment being $40 \%$, $43 \%, 44 \%$ and $45 \%$ in 1973, 1980, 1985 and 1989 respectively. The corresponding figures for secondary enrolment were 33\%, 35\%, 26\% and $42 \%$ respectively. However, in terms of percentage of school-age children, the ratios may have been lower.

For purposes of comparison, it should be mentioned that Nigeria's experience has been similar to most of the sub-Saharan Africa (SSA). According to the UNESCO World Education Report of 1991, gross enrolment rates at the primary school level fell from $77.1 \%$ in 1980 to $66.7 \%$ in 1990 . Secondary enrolment, on the other hand, rose from $16.8 \%$ in 1980 to $18.7 \%$ in 1985 , but fell to $17.5 \%$ in 1990 in SSA, while enrolment ratio at the university level rose almost fourfold from $0.5 \%$ to $1.9 \%$ in 1970 and 1990 respectively.

On female enrolment, the report noted that over the past two decades, the gap between male and female primary enrolment ratios had narrowed markedly in SSA as well as in the Arab States, although the, trend is less significant at the secondary and university levels. ${ }^{6}$

As in many other LDCs, declining enrolment ratios have been attributed to supply constraints and a fall in demand. On the demand side, faced with cost of education, parents tend to reduce the number of children in school and also tend to be selectively so in favour of sons (Gertler and Glewwe, 1992). On the supply side, this has been due to expenditure cutbacks. For example, Lockheed (1990) noted that "one reason that primary schools are unproductive in developing countries is that education systems are very poorly funded ... A study of countries undertaking structural adjustment over 1979-83 found that $68 \%$ reduced spending on education". And according to the UNESCO Report, total spending on education in SSA fell in real terms from $\$ 11$ billion to $\$ 7$ billion between 1980 and 1988. For a sample of 26 SSA countries, this translated into a decline in spending per pupil from $\$ 133$ to $\$ 89$. By contrast, average per pupil expenditure in the developed countries rose over the period from $\$ 1862$ to $\$ 2888$, while all other developing regions registered increases in their total education expenditure. Specifically in the case of Nigeria, educational allocations as a percentage of total public expenditure were $2.8 \%, 10.3 \%, 7.5 \%, 6.6 \%$ and $3.3 \%$ respectively in $1966,1975,1982,1990$ and $1991 .^{8}$

With growing school-age population and the demand for education, there have been calls for increased allocation of public funds to education both in Nigeria and in SSA in general in the 1990s. For example, although it 
recognised that, other factors also affect access to education, the UNESCO Report argues that progress toward attainment of the goal of "education for all (will) depend critically on national capacities to sustain higher levels of investment in education".

Thus, apart from calling for increased spending on education, toe Report also suggests that educational spending should be treated as investment in human capital.

One way of assessing whether or not investment in education is justified is to compare life time earning of people with a higher level of educational attainment with those with lower level of educational attainment. In other words, "the rate of return" analysis.

Direct returns to education can be examined from either the personal profit orientation or the national productivity orientation. The former focuses on differences in the net earnings of individuals with different levels of educational attainment as evidence of the level of personal financial benefit that can be associated with the attainment of a given level of education. This approach is relevant for the individual trying to make private calculations as well as for a country should be borne by the students. The latter approach considers education-related earnings differentials as an evidence of the effects of education on output, assuming that earnings are related to productivity.

Hansen (1963) estimated rates of return to investment in schooling in the United States. From this he observed that "while the rates of return of private resources investment obviously exceed those to total resource investment, we find (that) the marginal rates of return rise with more schooling up to the completion of Grade 8 and then gradually fall off to the completion of college". From this it was concluded that investment in education is beneficial to both the individual and society, and that "in spite of the flood of high school and college graduates, the return has not become trivial". Experience of other countries generally supports this conclusion (Psacharagpoulos, 1983).

Two points emerge from this conclusion. One is that marginal rate of return to education first raises up to a point after which it declines. Thus, it would be expected that the marginal rate of return is highest at the secondary level and lowest at the postgraduate level. The other is that increased supply of graduates would not result in a fall in earnings.

On the issue of gender gap, Gertler and Glewwe (1992) present results which suggest that there may be differential returns to education by sex. For example, from review of some earlier studies on Peru, it was observed that:

i. at the primary level the returns to education to men and women are quite similar in both urban and rural areas; and

ii. although the returns to secondary education are always statistically different from zero for men, it was not so for women.

From their own data, the authors concluded that, "the returns to secondary schooling has almost nil for women, while for men secondary schooling has significant returns in the wage labour market. Thus, secondary 
education may not be a rational investment for girls, but it does seem to be a rational investment for boys".

As mentioned above, the issue of labour market segmentation has also been examined within the returns to education context. Psacharapoulos (1983), using the human capital model, found that returns to education were higher in the private sector in the six countries covered (U.K, Greece, Portugal, Brazil, Columbia and Malaysia). Moreover, returns to education were found to be considerably higher in the private sector in the LDCs. This was then interpreted as evidence of labour market segmentation.

In the light of the foregoing, it is necessary to examine these issues in the case of Nigeria. Although Umo (1977) had investigated the issue of returns to education in Nigeria, the present paper goes beyond the scope of that paper in a number of areas. First, whereas that paper was based on data drawn from the Civil Service Staff List in Bendel State (now Edo and Delta States) in 1975, the present paper is based on individual data from a survey of households. Second, whereas that paper was concerned mainly with one issue, viz, the returns to education in Nigeria, using public sector data in a case-study, the present paper assumes less homogeneity of the labour force.

Thus, the issue is investigated in the context of the level of educational attainment, die gender debate, urban-rural dualism, and employment category. The Nigerian government has since 1987 been trying to encourage self-employment through its National Directorate of Employment programmes for young university graduates. The last level of categorisation would enable an assessment of the attractiveness of the strategy.

\section{HUMAN CAPITAL MODELS}

(i) Issue of Theory and the Model

Issue in human capital earnings function can be categorised into two. At one level is the pure human capital model, and at the other is the generalised or expanded human capital model. Both derive to a great extent from the work of Becker (1964) and Mincer (1974). The former considers only two factors as influencing earnings, namely, education (schooling) and labour market experience (post-school investment). The latter considers in addition sociological factors. The former has been adopted for this paper.

The basic assumption underlying the pure human capital is that investment in education is undertaken with the expectation of maximising the net discounted life time benefits accruing there from. Another assumption is that education enhances workers' productivity, and thereby earn higher wages. For this reason, workers would tend to undertake post-school or on-the-job training. These assumptions respectively form the basis of the two variables, in the model, namely, schooling (5) and experience (EX).

As Becker (1964) argues, training makes the life time earning curve steeper and more concave. This is because the rate of increase in earnings is affected more at younger than at older ages. As he puts it, "earnings of trained persons would be below marginal productivity during training period, and equal afterward, (hence) earnings would rise sharply at the end of the 
96 Annals of the Social Science Council of Nigeria, No. 4,1992.

training period and then level off, imparting a concave appearance to the curve as a whole". 12

This argument thus introduces a third variable into the model, viz. the quardratic of the experience variable $\left(E X^{2}\right)$.

$\operatorname{Ln} Y=a+b S+C E S+d E X^{2} Y-$

$Y \quad-\quad$ the earnings of the individual;

$S \quad$ - $\quad$ the number of years spent in school corresponding to the highest level of educational attainment; on the basis of the argument above, it is expected that $b$ the coefficient on the schooling variable, will have a positive sign; i.e. the increment in earnings is a positive function of total length of time spent schooling; $b$ could be interpreted as the rate of return to education;

$E X-\quad$ the number of labour market experience years, measured as Age less $S$ less $P$, where $P$ is the pre-schooling age, which in Nigeria is 6 years. The coefficient $C$ is expected to have a positive sign, the coefficient $C$ could be interpreted as the rate of return to training;

$E X^{2 \prime} \quad-\quad$ is introduced to capture the suggested parabolic decline in earnings with age. For the parabolic assumption to hold, the coefficient on the quadratic variable, $d$ must be negative and significant.

The semi-logarithmic specification derives from human capital theory, in which case the coefficient $b$ is interpreted as the private rate of return to education. The OLS method was used in implementing the model.

The data used for estimating the model were generated from a survey conducted between September 1990 and March 1991, covering 1971 and 1979 respondents respectively in Edo and Delta States of Nigeria. 
Education and Earning in Edo and Delta States 97

Table 1

ESTIMATES OF HUMAN CAPITAL EARNINGS FUNCTIONS, EDO STATE NIGERIA

\begin{tabular}{|c|c|c|c|c|c|c|}
\hline & & 5 & $E X$ & $E X^{2}$ & $R^{\prime 2}$ & $N$ \\
\hline $\mathrm{L}$ & All-State & $\begin{array}{l}0.029 * \\
(14.98)\end{array}$ & $\begin{array}{l}0.006^{*} \\
(2.79)\end{array}$ & $\begin{array}{l}-0.0003^{* *} \\
(-1.93)\end{array}$ & 0.22 & 1971 \\
\hline 1 & $\begin{array}{l}\text { Primary } \quad \& \\
\text { below }\end{array}$ & $\begin{array}{l}0.03 * \\
(2.32)\end{array}$ & $\begin{array}{l}0.004 * * * \\
(1.46)\end{array}$ & $\begin{array}{l}0.0003 * * * \\
(1.31)\end{array}$ & 0.20 & 209 \\
\hline 3. & Secondary & $\begin{array}{l}0.037 * * \\
(1.75)\end{array}$ & $\begin{array}{l}0.012 \\
(1.20)\end{array}$ & $\begin{array}{l}-0.003 \\
1.21)\end{array}$ & 0.20 & 154 \\
\hline 4. & $\begin{array}{l}\text { Post- } \\
\text { Secondary up } \\
\text { to B.Sc.) }\end{array}$ & $\begin{array}{l}0.256^{*} \\
(4.18)\end{array}$ & $\begin{array}{l}0.016 * * * \\
(1.46)\end{array}$ & $\begin{array}{l}-0.03 \\
1.25)\end{array}$ & 0.23 & 127 \\
\hline 5. & Males & $\begin{array}{l}0.029^{*} \\
(7.16)\end{array}$ & $\begin{array}{l}0.012 * \\
2.60)\end{array}$ & $\begin{array}{l}-0.001 * *(- \\
1.79)\end{array}$ & 0.21 & 465 \\
\hline 6. & Females & $\begin{array}{l}0.034 * * \\
(2.30)\end{array}$ & $\begin{array}{l}0.010 * * \\
(1.75)\end{array}$ & $\begin{array}{l}-0.0002 * * * \\
(-1.38)\end{array}$ & 0.20 & 32 \\
\hline 7. & $\begin{array}{l}\text { Self- } \\
\text { employed }\end{array}$ & $\begin{array}{l}0.034^{*} \\
5.37)\end{array}$ & $\begin{array}{l}0.010 * * * \\
(1.40)\end{array}$ & $\begin{array}{l}-0.0008 \quad(- \\
1.89)\end{array}$ & 0.20 & 282 \\
\hline 8. & Wage earners & $\begin{array}{l}0.028^{*} \\
(5.09)\end{array}$ & $\begin{array}{l}0.006 * \\
(2.72)\end{array}$ & $\begin{array}{l}-0.0002^{* *} \\
(-1.16)\end{array}$ & 0.21 & 198 \\
\hline 9. & Urban & $\begin{array}{l}0.027 * \\
5.83)\end{array}$ & $\begin{array}{l}0.008 * * * \\
(1.42)\end{array}$ & $\begin{array}{l}-0.0001 \quad(- \\
1.15)\end{array}$ & 0.21 & 300 \\
\hline $\begin{array}{l}1 \\
0 .\end{array}$ & Rural & $\begin{array}{l}0.021^{*} \\
(3.12)\end{array}$ & $\begin{array}{l}0.01 * * * \\
(1.33)\end{array}$ & $\begin{array}{l}-0.0002 * * \\
(-1.50)\end{array}$ & 0.20 & 204 \\
\hline
\end{tabular}

Notes: $\quad$ Figures in brackets are f-ratios $* 99 \%$ level of significance.

$* * 95 \%$ level of significance.

$* * * 90 \%$ level of significance. 
98 Annals of the Social Science Council of Nigeria, No.4,1992.

Table 2

\section{ESTIMATES OF HUMAN CAPITAL EARNINGS FUNCTIONS, DELTA STATE, NIGERIA}

\begin{tabular}{|c|c|c|c|c|c|c|}
\hline & & $S$ & $E X$ & $E X^{2}$ & $R^{2}$ & $N$ \\
\hline 1. & All-State & $\begin{array}{l}0.023^{*} \\
(8.62)\end{array}$ & $\begin{array}{l}0.002 * * \\
(2.2)\end{array}$ & $\begin{array}{l}-0.0006^{* *} \\
(-1.66)\end{array}$ & 0.20 & 1179 \\
\hline 2. & $\begin{array}{l}\text { Primary \&. } \\
\text { below }\end{array}$ & $\begin{array}{l}0.011^{*} \\
(3.75)^{\prime}\end{array}$ & $\begin{array}{l}0.006 \\
(1.09)\end{array}$ & $\mid \begin{array}{l}-0.0002 \\
1.07)\end{array}$ & 0.24 & 85 \\
\hline 3. & Secondary & $\begin{array}{l}0.016^{* *} \\
(2.10)\end{array}$ & $\mid \begin{array}{l}0.007 * * * \\
(1.62)\end{array}$ & $\begin{array}{l}0.0006 * * * \\
(-1.37)\end{array}$ & 0.24 & 85 \\
\hline 4. & $\begin{array}{l}\text { Post- } \\
\text { Secondary } \\
\text { (up to B.Sc.) }\end{array}$ & $\begin{array}{l}0.119^{*} \\
(4.94)\end{array}$ & $\begin{array}{l}0.014 \\
(1.24)\end{array}$ & $\begin{array}{l}-0.003 * * * \\
(-1.32)\end{array}$ & 0.20 & 94 \\
\hline 5. & Males & $\begin{array}{l}0.024 * \\
(4.54)\end{array}$ & $\begin{array}{l}0.004^{*} \\
(2.56)\end{array}$ & $\begin{array}{l}-0 .-0008 * \\
(-2.85)\end{array}$ & 0.20 & 275 \\
\hline 6. & Females & $\begin{array}{l}0.018^{*} \\
(2.72)\end{array}$ & $\begin{array}{l}0.014 * * \\
(1.69)\end{array}$ & $\mid \begin{array}{l}-0.0002 * * * \\
(-1.54)\end{array}$ & 0.18 & 25 \\
\hline 7. & $\begin{array}{l}\text { Self- } \\
\text { employed }\end{array}$ & $\begin{array}{l}0.012 * \\
(3.34)\end{array}$ & $\begin{array}{l}0.002 * * \\
(2.14)\end{array}$ & $\begin{array}{l}-0.0006 * * * \\
(-1.37)\end{array}$ & 0.20 & 130 \\
\hline 8. & Wage earner & $\begin{array}{l}0.038^{*} \\
(5.47)\end{array}$ & $\begin{array}{l}0.011 * * \\
(1.84)\end{array}$ & $\begin{array}{l}-0.002 * *(- \\
2.28)\end{array}$ & 0.25 & 151 \\
\hline 9. & Urban & $\begin{array}{l}0.02 * \\
(2.68)\end{array}$ & $\begin{array}{l}0.004 \\
1.14)\end{array}$ & $\begin{array}{l}0.0001 \\
(1.24)\end{array}$ & 0.21 & 179 \\
\hline $\begin{array}{l}1 \\
0 .\end{array}$ & Rural & $\begin{array}{l}0.027 * \\
(3.33)\end{array}$ & $\begin{array}{l}0.001 \\
(1.13)\end{array}$ & $\begin{array}{l}0.0005 \\
(1.30)\end{array}$ & 0.20 & 117 \\
\hline
\end{tabular}

Notes: Same as in Table 1. Also, secondary education used in the paper include Secondary Modern Three, Government Class IV, Secondary Commercial and GCE 'O' and 'A' Levels.

The sampling, which was done at random in selected urban and rural locations, was such that it was able to disaggregate the sample size by educational .level, by sex, and by employment category. The sample is considered to be representative enough of the population in each of the states 
and the two states are representative enough of the country in terms of access to education,' employment opportunities and earnings. The results from the analysis of the data could, therefore, be interpreted as being representative of the country.

\section{(ii) Estimated Results}

Estimated results from the model are reported in Tables 1 and 2 for Edo and Delta States respectively. In terms of overall explanation, $\left(R \sim^{2}\right)$, the results suggest that the human capital model reasonably fits the data used in the analysis, with the $R^{-2}$ being generally around $20 \%$, although it should be mentioned that the value of the $R^{-2}$ suggests that actual earnings in Edo and Delta States, as in the rest of Nigeria, may still be affected by othe ${ }^{r}$ Actors besides education and experience.

Another general observation is that the parabolic earnings function assumption of the human capital theory is supported in all but one case for Edo State and in all but two cases for Delta State in terms of the expected negative sign, and only in 4 and 3 cases respectively for Edo and Delta States are the estimated coefficient, $(d)$, not significant at $90 \%$ confidence level

The remaining hypotheses and assumptions mentioned above will now be verified with respect to each State, starting with Edo. Equation 1 reports results at the All-State level. It is observed that return to education is positive as expected and the coefficient is statistically significant at $99 \%$ confidence level. Estimated coefficient is, however, lower than what has been reported for other LDCs, ${ }^{14}$ suggesting that return to education is still generally low in Nigeria. The experience coefficient is also positive as expected, and the value is comparable with evidence on other countries.

Equations 2, 3, and 4 shed light on the assumption that return to education declines with increase in educational attainment. The reverse seems to be the case from the Nigerian evidence; i.e. estimated coefficient rises in value and level of significance with more education. This seems to suggest that productivity tends to improve with more education, hence higher returns to education for the more educated. Also, the results tend to support Hansens' (1963) observation that increases in supply of university graduates would not necessary make the returns to become trivial.

Equations 5 and 6 are concerned with dual labour market hypothesis on account of sex. It is observed that return to education is higher for females than for males. On the basis of this alone it could be argued that there is no incentive for sending more males (sons) than females (daughters) to school, contrary to what Gerler and Glewwe's evidence on Peru seems to suggest. ${ }^{15}$

However, the return to training coefficient or the experience variable is lower for females. This may be attributed to Mincer's (1974) observation that the definition of experience $(E X=A g e-S-P)$ is more relevant to labour market experience of males than of females as the former tends to accumulate rnore experience than the latter as a result of greater employment stability. ${ }^{16}$

Equations 7 and 8 assess dualism in terms of a wage earner versus sell employed dichotomy. Results suggest that return to education is marginally 
higher for the self-employed, although both are statistically significant at $99 \%$ level. The experience variables are also higher for the self-employed. This is probable not surprising because artisans, such as motor mechanics, really accumulate experience over the posttraining years; self-employment is quite popular with artisans, even those in government employment often resign early to establish own-enterprises on a broader level, the result suggests that self-employment is attractive, and therefore the Nigerian government's effort to promote self-employment through its National Directorate for Employment schemes may be yielding positive results.

Equations 9 and 10 assess dualism from the urban-rural context. Results suggest that return to education is higher in urban than rural areas. The estimated coefficients is higher and more statistically significant for urban areas, although the experience variables are slightly higher in rural areas. The latter is perhaps not surprising if one accepts the ageselectivity of migration theory that the young often are the first to migrate to urban areas, leaving behind the older members. Such members would, no doubt, be more experienced in whatever occupation they are engaged in by virtue of age and length of time they have been so engaged.

With respect to Delta State, Equation 1 presents estimates for All-State level of analysis. Estimated coefficients have the expected signs as in the case of Edo, but they are generally lower in value and level of significance. They are nonetheless significant at between $90 \%$ and $99 \%$ confidence level. The return to education, although positive, is still relatively low, as was also observed for Edo State. And as equations 2, 3 and 4 show, like in Edo State, return to education tends to rise with more education. This suggests that high premium is still placed on education in the two States.

Equations 5 and 6 show that return to education is higher for males. Although in both cases estimated coefficients are statistically significant, those for males are more significant. The argument on experience with respect to males in Edo State also applies. This may suggest dualism, and an incentive in favour of males (sons) and against females (daughters), lending some support to the Gertler and Glewwe argument.

Equations 7 and 8 indicate that return to education and return to training are both higher for wage earners, so also is the coefficient on the parabolic variable. Thus, unlike in the case of Edo State, wage employment is more attractive and earnings seem to suggest dualism. This may be due to the fact that Delta State is more industrialised, and particularly because of the oil and related services industry where earnings are usually very high.

Lastly, equations 9 and 10 examine urban-rural dualism Results show that return to education is slightly higher in rural areas, but the experience variable, which is wrongly signed in both sectors, is higher in urban areas. The higher return to education in rural areas may reflect the fact that the oil fields are in the rural areas.

\section{SUMMARY AND CONCLUSION}

An attempt has been made to assess the relevance of the Nigerian educational system as at present through the analysis of the return to education by level of 
education, employment category sector, as well as examine the on-going debate on gender gap in access to educational opportunities. Applying data from Edo and Delta States to the standard human capital model, the OLS estimates generated enabled some broad conclusions to be reached on the issues.

It should be cautioned that the possibility of some methodological and sampling errors would mean that the conclusions based on the analysis could not be taken as definitive. However, the similarity of the results with some others in the literature mentioned above gives some basis for confidence in the results.

Granted this caveat, the results show that, in general, the model fits the Nigerian data reasonably well. Specifically, the results have shown that:

i. return to education is positive, although relatively low;

ii. return to education tends to rise with more education;

iii. return to education appears higher for females in Edo State, while it is higher for males in Delta State;

iv. wage employment is more attractive than self-employment in Delta State, while there is no marked difference in return to education in Edo State; and

v. while return to education is higher in rural areas of Delta, the reverse is the case in Edo State.

The overall conclusion from the foregoing is that there is a consistent pattern in the two States with respect to the robustness of the model, and with respect to the fact that return to education rises with education, at least, up to the university level. This suggests that high premium is still being placed on education in the States, perhaps reflecting the stage of development of the country.

Although there is a less consistent pattern among the States with aspect to return to education by sex, employment category and sector, there appears to be some support for the dual labour market hypothesis in the States. It must be added though that these results could only be interpreted as a rough indication of existence of dual labour market since wage only forms a part of labour market conditions. There was no way of assessing any of these other conditions from the results (see footnote 15 below). Nonetheless, the fact that education appears rewarded differentially by sex, employment category and sector is suggestive of existence of some factors which differentiate same in not necessarily an institutionalised way. This subsequently points to an area requiring further research.

Some policy considerations also derive from these results. First, the positive effects of education and post-school training on earnings suggest the need to improve facilities in our educational institutions for more adequate and effective training in schools and post-school (on-the-job, in-service) training. The present tendency to cut back on educational spending at the slightest sign of economic problems (whereas such spendings as on defence are less affected) would therefore need to be reversed. 
Second, the fact that return to education is still low and toe implied concave earnings profile suggests that there may be the need to find ways of raising return to education. Unless this is done we may find that earnings begin to taper off with time even from an already low level, which would not be desirable, considering the equity effect of inflation on low and fixed pension income.

Third, although the issue of rural-urban migration has not been examined in this paper, the existence of a higher return to education in urban areas would no doubt have implications for rural-urban migration. There would, therefore, be the need to reduce, if not eliminate such a differential, lest it precipitates exodus from rural areas. An example of what is required is to boost the level of rural industrialisation to raise average earnings level.

And fourth, existence of "segmented" labour markets also has implication for equity. It would be necessary to eliminate such differentials so as to promote equity. 
Education and Earning in Edo and Delia States 103

\section{FOOTNOTES}

${ }^{1}$.Financial support for the survey for this paper was provided by the Research Grants Committee of Edo State University, Ekpoma.

${ }^{2}$.See, for example, Gertler and Glewwe (1992).

${ }^{3}$.Analysis have tended to concentrate only on males to avoid issues of sex discrimination, see for example Psacharapoulos (1983), p. 124.

${ }^{4}$.The Global Coalition for Africa, ^992 Annual Report, Washington D.C. (November).

5. This was still the lowest third level enrolment rate in the world, with East Asia recording $6.1 \%$ and North Africa $10.5 \%$ in 1988. See "United Nations Africa Recovery Briefing Paper, 1992," (April), p.12.

${ }^{6}$ United Nations, op. cit, p. 13.

${ }^{7}$ Lockheed (1990), p. 24 and United Nations, op. cit, p. 12.

${ }^{8}$ Central Bank of Nigeria Annual Report of various years. It should be mentioned that in Nigeria there is a gap between allocation and disbursement; actual disbursements are often less than allocation.

${ }^{9}$ UNESCO World Education Report 1991, reviewed and quoted in United Nations, op. cit, p. 12. See also The Global Coalition for Africa, op. cit, pp. 12-13.

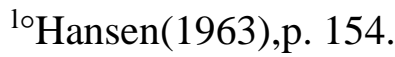

${ }^{11}$ Gertler \& Glewwe (1992), pp. 176-77.

${ }^{12}$ Becker (1963), p.192.

${ }^{13}$ The socio-cultura! factors in Nigeria sucn as nepotism and ethnicism or the "federal character" considerations in offer of appointment come to mind. It is nonetheless interesting to note that in terms of the value of $R^{\prime \prime}$, this evidence on Nigeria is similar to that reported for the U.K. and Portugal in Psacharapoulos (1983).

${ }^{14}$ Psacharapoulos reported values ranging from 0.133 to 0.225 for $\mathrm{Bra} / \mathrm{il}$, Colombia, and Malaysia in a study that is concerned only with wage earners.

${ }^{15}$ This result, it has to be said, is a little curious since there is no sex discrimination with respect to pay in the Nigerian labour market so long as applicants have the same educational qualification.

${ }^{16}$ J. Mincer (1974) Schooling, Experience and Earnings: New York, NBER, p.

17, quoted in Umo (1977), pp.144. 
104 Annals of the Social Science Council of Nigeria, No.4.1992.

\section{REFERENCES}

1. Becker, G.S. (1964) "Investment in on-the-job Training" in M. Biaug (ed) (1968) Economics of Education II, London, Penguin, pp. 183-207.

2. Bowen, W.G. (1963) "Assessing the Economic Contribution of Education" in M. Blaug (ed), (1968), pp. 67-100

3. Gertler, P. \& Glewwe, P. (1992) "The willingness to pay for education for Daughters in contrast to Sons: Evidence from rural Peru" in World Bank Economic Review (January), pp. 171-88.

4. Hansen, W.L. (1963) "Rates of Return to Investment in Schooling in the United States", in M. Blaug (ed), (1968), pp. 137-55.

5. Lockheed, M. (1990) "Improving Primary Schools in Developing Countries", in Finance and Development, (March), pp. 24-26.

6. Psacharapoulos, G. (1983) "Education and Private versus Public Sector in Pay", in Labour \& Society, Vol. 8, No. 2 (April- June), pp. 123-34. Also, World Dank, Reprint Series, No. 345.

7. Umo, J.E. (1977) "The Pure Human Capital Investment Model: Some Empirical Tests and Income Distributional Implications for an LDC", in Nigerian Journal of Economic and Social Studies, (July), pp. 135-51.

8. UNECA (1992) "Falling Public Spending Reverses Gains in African Education" in Africa Recovery Briefing Paper, (April), pp. 12-13.

9. Vespor, A, (1990) "Educational Development: Priorities for the Nineties", in Finance and Development, (March), pp. 20-23. 